\title{
A Right Middle Cerebral Artery Infarct After Frontal Eosinophilic Granuloma Resection in an 8-Year-Old Boy with Factor V Leiden
}

\section{Faktör V Leiden Tanılı 8 Yaşında Erkek Çocukta Eozinofilik Granülom Rezeksiyonu Sonrası Gelişen Sağ Orta Serebral Arter Infarktı}

\author{
Ertugrul CAKIR ${ }^{1}$, Erhan ARSLAN ${ }^{2}$, Ugur YAZAR $^{1}$, Gokce Pinar REIS 3 \\ ${ }^{1}$ Karadeniz Technical University, School of Medicine, Department of Neurosurgery, Trabzon, Turkey \\ ${ }^{2}$ Giresun University, School of Medicine, Department of Neurosurgery, Giresun, Turkey \\ ${ }^{3}$ Karadeniz Technical University, School of Medicine, Department of Pediatric Hematology, Trabzon, Turkey
}

Corresponding Author: Erhan ARSLAN / E-mail: arserhan@gmail.com

\begin{abstract}
Stroke in children is relatively uncommon. We describe an 8-year-old boy diagnosed with primary eosinophilic granuloma (EG) of the frontal bone. After excision of the EG, the postoperative course was eventful. The patient had an acute right middle cerebral artery (MCA) infarct and had been comatose with a diminished Glasgow Coma Scale (GCS) score of 5. Urgent decompressive hemicraniectomy with duraplasty was performed. The postoperative course after the second operation was uneventful. Hematological tests revealed a diagnosis of factor $V$ Leiden. The patient was discharged with left hemiparesis and GCS of 15. To the best of our knowledge, no such clinical picture of MCA infarction after EG excision has been described before. Neurosurgeons should be aware of inherited thrombophilias, such as factor $V$ Leiden, if the postoperative clinical course worsens because of cerebral artery thrombosis. Also, decompressive hemicraniectomy could be life saving and should be performed urgently without any hesitation.
\end{abstract}

KEYWORDS: Decompressive hemicraniectomy, Eosinophilic granuloma, Factor V Leiden, Middle cerebral artery stroke

öz

Çocuklarda inme göreceli olarak nadirdir. Frontal kemikte primer eozinofilik granülom (EG) tanısı almış 8 yaşında erkek çocuk hastayı sunmaktayız. EG'nin eksizyonundan sonra, postoperatif seyir beklenmedik şekilde gelişti. Hasta akut sağ orta serebral arter (OSA) infarktı geçirip, Glasgow Koma Puanı (GKP) 5'e düşüp, koma halini aldı. Acil dekompresif hemikraniyektomi ve duraplasti yapıldı. İkinci operasyondan sonra hastanın postoperatif seyri olağandı. Hematolojik testlerde faktör V Leiden teşhisi konuldu. Hasta GKP 15 ve sol hemiparezi ile taburcu edildi. Bilgilerimiz ışığında, EG eksizyonu sonrası OSA infarktı olan bu şekilde bir klinik tablo henüz bildirilmemiştir. Eğer serebral arter trombozundan dolayı postoperatif klinik gidişat kötüleşir ise, nöroşirürjiyenler faktör $V$ Leiden gibi kalıtımsal trombofililerin de bu durumun sebebi olabileceğinin farkında olmalıdırlar. Ayrıca dekompresif hemikraniyektomi, bu gibi inme durumlarında acilen ve tereddütsüz olarak uygulandığında hayat kurtarıcı olabilir.

ANAHTAR SÖZCÜKLER: Dekompresif hemikraniyektomi, Eosinofilik granülom, Faktör V Leiden, Orta serebral arter inmesi

\section{CASE ILLUSTRATION}

An 8-year-old boy was referred to our outpatient clinic with swelling in the right frontal region and headache around the right ear. Cranial computed tomography (CT) showed a bone defect at the right frontal bone (Figure 1A). A mass, 27x11 $\mathrm{mm}$ in size with typical eosinophilic granuloma, isointense to gray matter on T1W images (Figure 1B) and slightly hyperintense to gray matter on T2W images (Figure 1C) at cranial magnetic resonance imaging (MRI) was observed. The neurosurgery clinic was consulted. Once preoperative preparations including bleeding and coagulation times, were completed, the mass was resected totally, together with a sound area of skull bone. There was no evidence of dural infiltration by the tumor. Histopathological examination revealed eosinophilic granuloma with typical Langherhans cells and eosinophilic infiltration. Postoperative course was eventful. At the 5th hour postoperatively, the patient suffered a focal seizure with shaking of the left lips and jaw. In the postictal period, the patient was unconscious with a left hemiparesis (grade 2 on the muscle strength test) and Glasgow Coma Scale (GCS) score was 9. The pediatric neurology department was immediately consulted. Bolus infusion of phenytoin sodium at $20 \mathrm{mg} / \mathrm{kg} / \mathrm{h}$ for 30 minutes was performed. Phenytoin sodium was continued at $5 \mathrm{mg} / \mathrm{kg}$ qid. Dexamethasone $0.25 \mathrm{mg} / \mathrm{kg}$ qid and furosemide $1 \mathrm{mg} / \mathrm{kg}$ bid were also added to the medical therapy. As the dura was not opened during surgery, Todd's paralysis after seizure attack was suspected and electroencephalography (EEG) was performed. Cranial CT on the same day was consistent with slight cerebral edema (Figure 2A). The patient's 
left motor weakness progressively increased to hemiplegia, and GCS decreased to 7. Urgent cranial MRI was performed. Cranial MRI with diffusion weighted images revealed an acute cerebral infarct in the water shedding area of the right middle cerebral artery (MCA) and ventricular shifting towards the left side (Figures $2 \mathrm{~B}, \mathrm{C}$ ). Digital substraction angiography (DSA) was immediately performed. This revealed severe stenosis of the right internal carotid artery (ICA) just before the bifurcation, and occluded right MCA from the point of origin. Blood flow in the left ICA was normal. No filling of the right ICA and MCA by the way of the anterior communicating artery (Aco$m A$ ) was observed (Figure 2D). The patient was transferred to the intensive care unit (ICU). Information about the patient's clinical course was given to the parents, during which we obtained further details regarding his familial history. We learned that the patient's sister, who was 3 years older than him, also had cerebral infarct after a minor head trauma. She had experienced a left upper extremity monoparesis. The patient was examined by the pediatric hematology department. Anticoagulant (enoxaparin sodium) at $100 \mathrm{U} / \mathrm{kg}$ bid was started, and $70 \mathrm{mg} /$ day acetylsalicylic acid was added. Blood levels of protein C, protein S, homocysteine, lipoprotein (a) and factor VIII, and prothrombin time (PT) and partial thromboplastin time (PTT) were normal. Blood tests using SNaPshot revealed no prothrombin G20210A mutation. However, the patient was heterozygous for factor $V$ Leiden, and heterozygous for methylenetetrahydrofolate reductase (MTHFR) C677T mutation. His sister's and parents' blood were also analyzed. His sister was homozygous for the MTHFR C677T mutation, and the father and mother were heterozygous for the MTHFR C677T mutation. The patient's ECHO cardiogram and Doppler ultrasonography revealed no other thrombus in the cardiovascular system. His clinical condition worsened, and GCS decreased to 5 . We performed urgent right fronto-temporoparietal decompressive craniectomy with duraplasty (Figure 3A). The patient was observed in the ICU in an intubated state. The post- operative course after decompressive hemicraniectomy was uneventful. The patient was extubated on the $15^{\text {th }}$ day postoperatively. At neurological examination, GCS was 14 with left hemiplegia. Passive exercises were started in the ICU. On the $20^{\text {th }}$ day postoperatively, the patient was transferred to a bed in the neurosurgery clinic. On the $45^{\text {th }}$ day postoperatively, the removed skull bone was replaced on the cranial defect (Figure 3B). The patient was transferred to physical therapy and rehabilitation clinic 2 months after the first operation with left hemiparesis (grade 2 on the lower extremity muscle strength test and grade 1 on the upper extremity muscle strength test). The patient showed improvements in motor power. By the $6^{\text {th }}$ month after the first operation, he had grade 4 muscle strength in the left lower extremity and grade 3 muscle strength in the left upper extremity. On discharge, the patient was able to walk without assistance.

Eosinophilic granuloma (EG) is considered a benign histiocytosis of unknown etiology. It is characterized by single or multiple skeletal lesions. It predominantly affects children, adolescents and young adults, although it may be encountered at all ages. Solitary lesions are more common than multiple ones. The more common sites for EG include the skull, mandible, spine, ribs and long bones (1). The usual treatment of solitary EG of the skull consists of a craniectomy, or curettage if necessary, followed by local radiation therapy (1). As the usual treatment of solitary EG is resection of the mass, we excised the frontal EG using craniectomy in our patient. The patient's preoperative hematological tests, including PT and PTT, were within normal limits. The patient suffered an unexpected arterial ischemic stroke on the first postoperative day.

Stroke in children is a heterogeneous disorder. Multiple risk factors for stroke have been reported, and genetic predisposition to stroke has been confirmed (5). The incidence of stroke in children is estimated at between 2.6 and 6.4 per 100,000 per year, with a higher frequency in the current

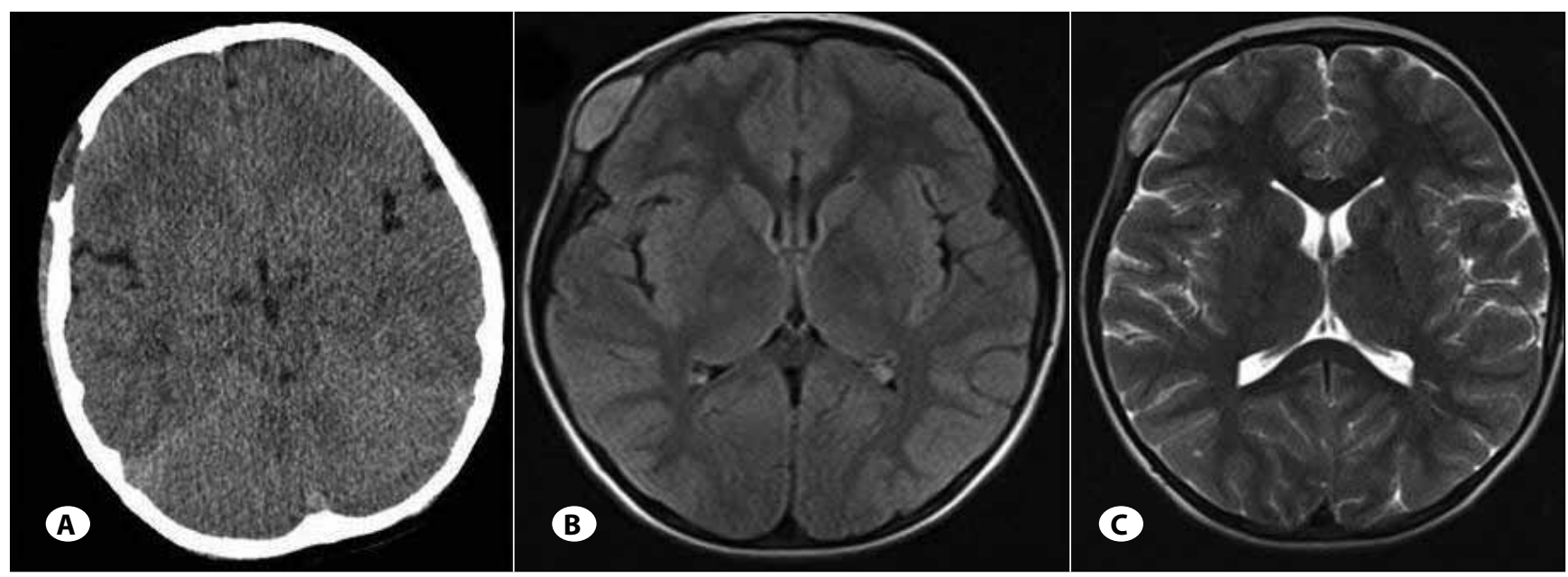

Figure 1: A) Axial computed CT scan showing an osteolytic lesion in the right frontal bone on the right side. B) Axial T1W MRI scan showing a lesion isointense to gray matter, C) axial T2W MRI scan showing a lesion slightly hyperintense to gray matter in the right frontal bone. 
literature (2). In children up to age 14, the incidence of stroke ranges from 2 to 8 per 100,000 (3).The most frequently reported risk factors for stroke are congenital heart malformations, hemolytic anemias, collagen vascular diseases and some rare congenital metabolic disorders. Trauma, infectious diseases, and thrombophilias are also included among the risk factors (5). In up to $30 \%$ of children, risk factor cannot be established, despite extensive investigations (5).

The well-established inherited thrombophilic risk factors are deficiency of antithrombin, protein $\mathrm{C}$, and protein $\mathrm{S}$, factor $\mathrm{V}$ Leiden and factor II G20210A (5). Several studies have reported an increased frequency of factor $\mathrm{V}$ Leiden in childhood arterial ischemic stroke (5). Kenet et al. (2) reported that metaanalysis showed a significant association between arterial ischemic stroke and FV Leiden and PT G20210A. Our case had an inherited thrombophilic risk factor (factor $\mathrm{V}$ Leiden). The first operation (excision of EG) was also another risk factor for arterial thrombosis. Both of these thrombophilic factors may have led to MCA thrombosis in this child. Stroke in children results in significant morbidity and mortality. Brain swelling and subsequent cerebral herniation is the usual cause of early death after acute stroke. Medical treatments may help to
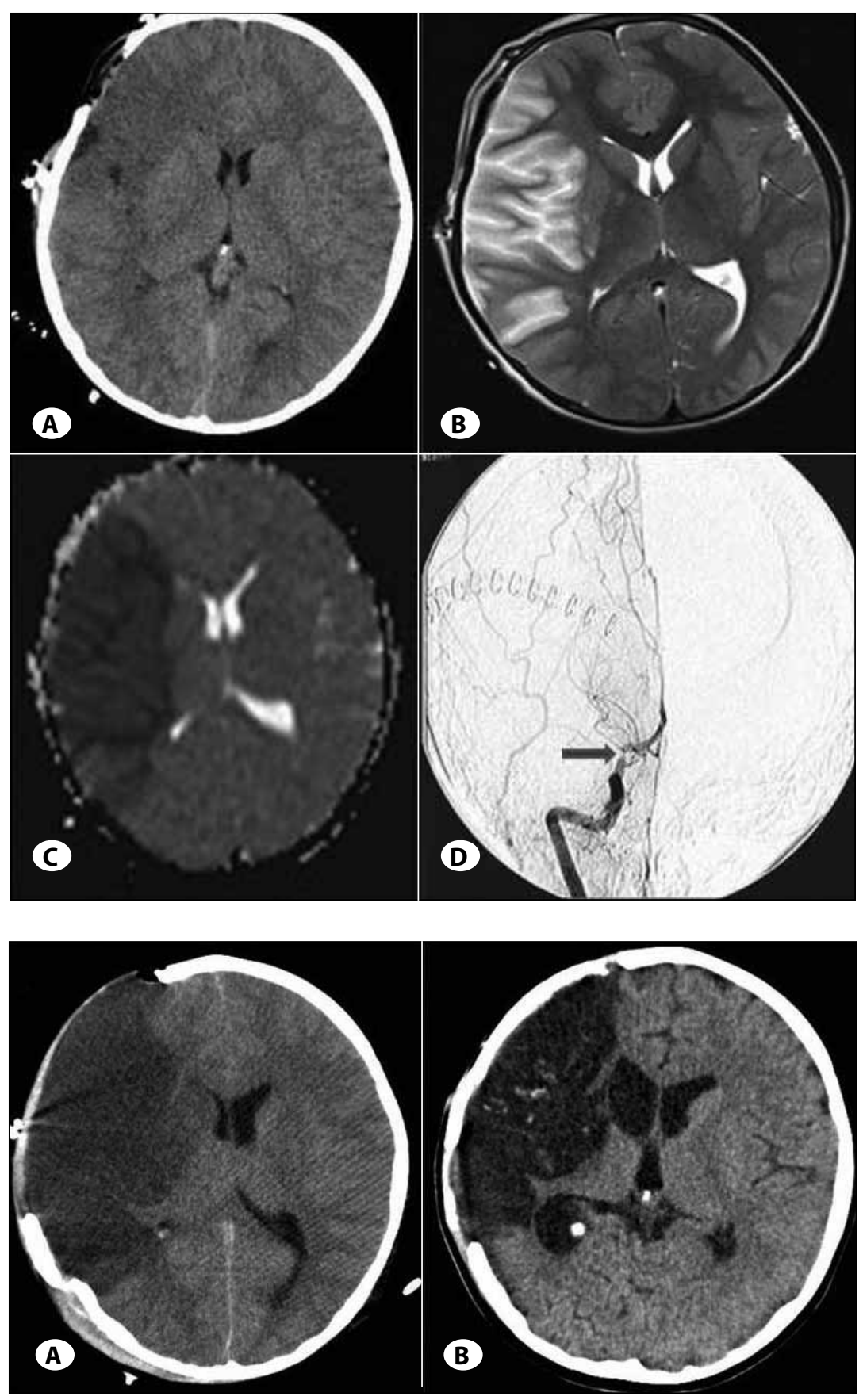

Figure 2: A) Axial CT scan taken on the first postoperative day showing the right frontal bone defect and slight hypointensity and effacement of sulci in the right frontoparietal region. B) Axial T2W MRI scan demonstrating hyperintensity in the area of the right middle cerebral artery (MCA). C) Apparent Diffusion Coefficient (ADC) showing hyperintensity in the area of the right MCA due to acute cerebral infarct. D) A frontal view of the right carotid angiogram showing thrombus formation within the right internal carotid artery (ICA) just before it bifurcates, and excessive stenosis in this segment (arrow). Note that there is no blood flow in the right MCA, due to thrombosis.

Figure 3: A) Axial computed CT scan after decompressive hemicraniectomy showing the right cerebral infarct with ventricular midline shifting. Note the swollen cerebral parenchyma extending through the cranial defect. B) Computed CT scan after replacement of the removed skull bone showing the right frontoparietal chronic infarct with pulling of the right lateral ventricle to this encephalomalacic site. 
control intracranial hypertension. However, failure of medical therapy and progressive worsening of clinical condition, as in our patient, necessitate surgical decompression. Optimal timing of decompressive craniectomy remains controversial (4). If signs of herniation and midline shift appear at cranial CT or MRI, surgery should be considered. Recent studies have reported that if decompressive craniectomy is performed early the procedure reduces mortality and also improves functional outcomes (4). The potential life saving benefit of decompressive craniectomy has been shown in the literature and in our experience with our patient.

We report an 8-year-old boy undergoing EG excision from the skull and decompressive hemicraniectomy for right MCA infarct due to factor $V$ Leiden. The lesson we have learned from this patient is familial history must be taken from the parents with great care, and only this may prevent postoperative morbidity and mortality. Inherited thrombophilias (e.g, factor $\mathrm{V}$ Leiden and MTHFR mutations) must be kept in mind if cerebral arterial thrombosis occurs in a child. We would also emphasize the importance of decompressive hemicraniectomy. This can be life-saving if performed in patients with life-threatening brain swelling refractory to medical treatment.

\section{REFERENCES}

1. Kahilogullari G, Tuna H, Kuzu I, Unlu A: Orbital eosinophilic granuloma in a child: A case report. Turk Neurosurg 23(4):575577, 2013

2. Kenet $G$, Lütkhoff $L K$, Albisetti $M$, Bernard $T$, Bonduel $M$, Brandao L, Chabrier S, Chan A, deVeber G, Fiedler B, Fullerton HJ, Goldenberg NA, Grabowski E, Günther G, Heller C, Holzhauer S, lorio A, Journeycake J, Junker R, Kirkham FJ, Kurnik K, Lynch JK, Male C, Manco-Johnson M, Mesters R, Monagle $\mathrm{P}$, van Ommen $\mathrm{CH}$, Raffini L, Rostásy $\mathrm{K}$, Simioni $\mathrm{P}$, Sträter RD, Young G, Nowak-Göttl U: Impact of thrombophilia on risk of arterial ischemic stroke or cerebral sinovenous thrombosis in neonates and children: A systematic review and meta-analysis of observational studies. Circulation 121(16):1838-1847, 2010

3. Shatla HM, Tomoum HY, Elsayed $\mathrm{SM}$, Aly $\mathrm{RH}$, Shatla $\mathrm{RH}$, Ismail MA, El-Ghany NA, Fakhry Al, Abd Allah NA, Yonca E, Nejat AM: Inherited thrombophilia in pediatric ischemic stroke: An Egyptian study. Pediatr Neurol 47(2):114-118, 2012

4. Tan MA, Salonga AM, Jamora RD: Decompressive hemicraniectomy in a 2-year-old girl with a left middle cerebral artery infarct. Childs Nerv Syst 22(5):523-525, 2006

5. Zadro R, Herak DC: Inherited prothrombotic risk factors in children with first ischemic stroke. Biochem Med (Zagreb) 22(3):298-310, 2012 